\title{
Copper catalysed synthesis of indolylquinazolinone alkaloid bouchardatine
}

\author{
MAYAVAN VIJI and RAJAGOPAL NAGARAJAN* \\ School of Chemistry, University of Hyderabad, Hyderabad 500 046, India \\ e-mail:rnsc@uohyd.ernet.in; naga_indole@yahoo.co.in
}

MS received 7 January 2014; revised 1 April 2014; accepted 1 April 2014

\begin{abstract}
We describe the total synthesis of indolylquinazolinone alkaloid bouchardatine and some of the quinazolinone derivatives. The aerobic oxidation induced by copper(I) bromide, followed by Vilsmeier-Haack formylation gives the natural product bouchardatine alkaloid in good yield.
\end{abstract}

Keywords. Bouchardatine; Vilsmeier-Haack formylation; indolylquinazolinone alkaloid

\section{Introduction}

2,3-Dihydroquinazolin-4(1H)-ones are an important class of privileged compounds which have a range of applications in many areas of chemistry and are frequently found in many natural products. ${ }^{1}$ As a result, numerous efforts have focused in the past few decades on the construction of quinazolinone alkaloids which are well-documented in a broad range of scientific journals. ${ }^{1-6}$ Moreover, quinazolinone derivatives have drawn renewed attention as new drug delivery technologies and exhibit a wide range of biological and medicinal activities; used as anti-tumor, anti-defibrillatory, analgesic, diuretic, CNS stimulant, anti-histamine, anti-hypertensive, vasodilating agent, and also used as inhibitor of various enzymes (figure 1 ). ${ }^{2}$

Bouchardatine is an indolylquinazolinone alkaloid that was isolated from the aerial part of Bouchardatia neurococca. It belongs to the family of Rutaceae and subfamily rutoideae; ${ }^{3}$ and it is a monotypic genus that has been collected from Australia. ${ }^{4,5}$ In view of its important pharmacological as well as biological properties, a careful analysis of literature disclosed that there are only two reports available for the synthesis of the bouchardatine alkaloid. ${ }^{6}$

Over the last few decades, transition metal-catalyzed formation of C-C and $\mathrm{C}-\mathrm{N}$ bonds has attracted increasing attention and found wide applications in organic synthesis. $^{7}$ These days, this field has been mainly dominated by palladium catalyst. ${ }^{8}$ However, the development of less expensive and environmentally amiable catalysts is still desirable for organic synthesis. Copper catalysts are relatively cheap, easy to handle, and hold

*For correspondence a fine position in comparison with the other transition metal catalysts used in organic synthesis. Therefore, during the past decade, large numbers of novel and useful reactions using copper catalyst have been reported in literature. ${ }^{9}$

The reported methods ${ }^{6}$ for the synthesis of bouchardatine were reported, either via harsher reactions condition or multi-step sequence. Therefore, we are interested in identifying mild reaction conditions for the construction of quinazolinone alkaloids. Herein, we report a mild and effective method for the synthesis of bouchardatine, starting from indole-2-aldehyde with anthranilamide through copper(I) bromide mediated aerobic oxidation reaction as shown in scheme 1 .

\section{Experimental section}

\subsection{General information}

All ${ }^{1} \mathrm{H},{ }^{13} \mathrm{C}$ NMR spectra were recorded on AV-400 spectrometer operating at 400 and $100 \mathrm{MHz}$ respectively. Chemical shifts for ${ }^{1} \mathrm{H}$ NMR are expressed in parts per million (ppm) relative to tetramethylsilane $(\delta$ $0.00 \mathrm{ppm})$. Chemical shifts for ${ }^{13} \mathrm{C}$ NMR are expressed in ppm relative to $\mathrm{CDCl}_{3}(\delta 77.0 \mathrm{ppm})$. Multiplicities were indicated as follows $(\mathrm{s}=$ singlet, $\mathrm{d}=$ doublet, $\mathrm{t}=$ triplet, $\mathrm{q}=$ quartet, $\mathrm{m}=$ multiplet, and coupling constants (Hz). Chemical shifts of common trace ${ }^{1} \mathrm{H}$ NMR impurities $\left(\mathrm{CDCl}_{3}, \mathrm{ppm}\right): \mathrm{H}_{2} \mathrm{O}, 1.56$; EtOAc, 1.26 , 2.05, 4.12; $\mathrm{CH}_{2} \mathrm{Cl}_{2}, 5.30 ; \mathrm{CDCl}_{3}, 7.26$. IR spectra were recorded on FT/IR-5300 spectrometer; absorptions are reported in $\mathrm{cm}^{-1}$. Mass spectra were recorded on either using EI technique or LCMS-2010A mass spectrometer. Elemental analyses $(\mathrm{C}, \mathrm{H}$ and $\mathrm{N})$ were recorded on 
<smiles>O=Cc1c(-c2nc3ccccc3c(=O)[nH]2)[nH]c2ccccc12</smiles>

Bouchardatine<smiles>O=Cc1c(-c2nc3cc(O)ccc3c(=O)[nH]2)[nH]c2ccccc12</smiles>

Orirenierine A

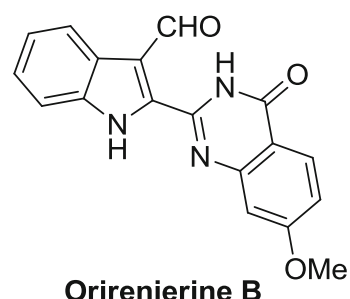

Orirenierine B

Figure 1. Indolylquinazolinone alkaloids.

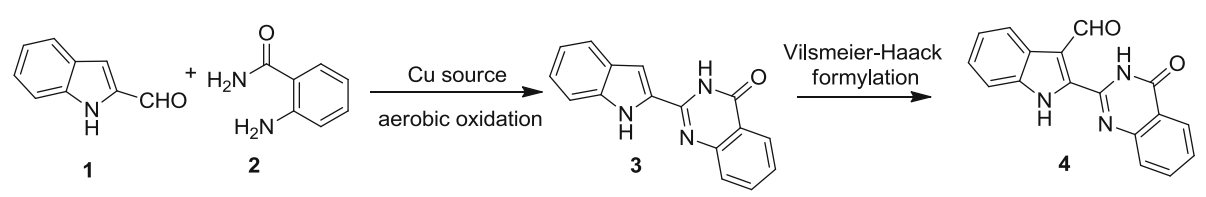

Scheme 1. Schematic representation of the present work.

EA 1112 analyzer in the School of Chemistry, University of Hyderabad. Routine monitoring of the reactions was performed by TLC silica gel 60 F254 plates. Compounds were visualized with UV light at $254 \mathrm{~nm}$. Further visualization was achieved by staining with iodine. Column chromatography was carried out employing neutral alumina. Commercially available reagents and solvents were used without further purification. Melting points were measured in open capillary tubes.

2.1a General procedure for the synthesis of 2-(1Hindol-2-yl)quinazolin-4(3H)-one (3): An oven dried $25 \mathrm{~mL}$ round bottom flask was charged with a magnetic pellet and $\mathrm{CuBr}(10 \mathrm{~mol} \%)$, indole-2-aldehyde 1 (1.0 equiv.), DMF (3 $\mathrm{mL})$ along with anthranilamide 2 (1.0 equiv.), $\mathrm{Cs}_{2} \mathrm{CO}_{3}$ (3.0 equiv.) and it was stirred at $120^{\circ} \mathrm{C}$ for $2 \mathrm{~h}$ in open air. After completion of the reaction, followed by thin layer chromatography (TLC), the reaction mixture was poured into water and extracted with EtOAc $(3 \times 10 \mathrm{~mL})$, dried over anhydrous $\mathrm{Na}_{2} \mathrm{SO}_{4}$, and then concentrated under reduced pressure to give a crude product. The crude product was purified by column chromatography on neutral alumina using hexanes/EtOAc as the eluent. The solvent was evaporated to dryness to get the pure product 3 in $94 \%$ yield.

2.1b 2-(1H-Indol-2-yl)quinazolin-4(3H)-one (3): White colored solid; yield: $94 \%$, Mp: $270^{\circ} \mathrm{C}$, IR (KBr) $v_{\max }: 3424,2964,2926,2849,1676,1594,1336$, $1309,865,777 \mathrm{~cm}^{-1} ;{ }^{1} \mathrm{H}$ NMR (400 MHz, DMSO- $d_{6}$ ): $\delta 12.62(\mathrm{~s}, 1 \mathrm{H}), 11.81(\mathrm{~s}, 1 \mathrm{H}), 8.14(\mathrm{~d}, 1 \mathrm{H}, J=7.8 \mathrm{~Hz})$, $7.84(\mathrm{t}, 1 \mathrm{H}, J=7.6 \mathrm{~Hz}), 7.74-7.72(\mathrm{~m}, 1 \mathrm{H}), 7.65(\mathrm{~s}$, $1 \mathrm{H}), 7.63(\mathrm{~d}, 1 \mathrm{H}, J=8.0 \mathrm{~Hz}), 7.53-7.49(\mathrm{~m}, 2 \mathrm{H}), 7.22$ $(\mathrm{t}, 1 \mathrm{H}, J=7.0 \mathrm{~Hz}), 7.05(\mathrm{t}, 1 \mathrm{H}, J=7.2 \mathrm{~Hz}) ;{ }^{13} \mathrm{C} \mathrm{NMR}$ $\left(125 \mathrm{MHz}, \mathrm{DMSO}-d_{6}\right): \delta 162.2,149.2,147.0,138.1$, $135.1,130.5,127.9,127.4,126.7,126.5,124.5,122.0$, 121.6, 120.4, 112.8, 105.4. LC-MS (m/z): $262(\mathrm{M}+\mathrm{H})^{+}$ positive mode; Anal. calcd. for $\mathrm{C}_{16} \mathrm{H}_{11} \mathrm{~N}_{3} \mathrm{O}$ : C, 73.55; $\mathrm{H}, 4.24 ; \mathrm{N}, 16.18 \%$, found: $\mathrm{C}, 73.31 ; \mathrm{H}, 4.31 ; \mathrm{N}$, $16.12 \%$.

2.1c General procedures for the synthesis of 2(4-oxo-3,4-dihydroquinazolin-2-yl)-1H-indole-3carbaldehyde (4): Phosphoryl chloride (9.0 equiv.) was dissolved in $3 \mathrm{~mL}$ of anhydrous DMF and stirred at $0^{\circ} \mathrm{C}$. Then 1.0 equiv. of 3 was dissolved in $4 \mathrm{~mL}$ of DMF added dropwise to the reaction mixture. The mixture was stirred at $0^{\circ} \mathrm{C}$ for $24 \mathrm{~h}$, then this solution was added dropwise to $7 \mathrm{~mL}$ of saturated sodium bicarbonate solution. $5 \mathrm{~mL}$ of $10 \% \mathrm{NaOH}$ solution were poured onto the mixture, and the precipitated solid was filtered off and washed with water. Recrystallization from hot ethanol provided a pale yellow colored solid 4 in $91 \%$ yield.

2.1d 2-(4-Oxo-3,4-dihydroquinazolin-2-yl)-1H-indole3-carbaldehyde (4): Yellow colored solid; yield: $91 \%, \mathrm{Mp}:>280^{\circ} \mathrm{C}$, IR $(\mathrm{KBr}) v_{\max }: 3462,2986$, 2875, 2821, 1718, 1693, 1562, 1432, 1317, 1223, 865, $750 \mathrm{~cm}^{-1} ;{ }^{1} \mathrm{H}$ NMR (400 MHz, DMSO- $\left.d_{6}\right): \delta 13.65$ $(\mathrm{s}, 1 \mathrm{H}), 13.13(\mathrm{~s}, 1 \mathrm{H}), 10.4(\mathrm{~s}, 1 \mathrm{H}), 8.26(\mathrm{~d}, 1 \mathrm{H}, J=$ $8.0 \mathrm{~Hz}), 8.20(\mathrm{~d}, 1 \mathrm{H}, J=8.0 \mathrm{~Hz}), 7.92-7.89(\mathrm{~m}, 1 \mathrm{H})$, $7.85-7.83(\mathrm{~m}, 1 \mathrm{H}), 7.68(\mathrm{~d}, 1 \mathrm{H}, J=8.0 \mathrm{~Hz}), 7.59(\mathrm{t}$, $1 \mathrm{H}, J=7.6 \mathrm{~Hz}), 7.41(\mathrm{t}, 1 \mathrm{H}, J=7.2 \mathrm{~Hz}), 7.36-7.32$ $(\mathrm{m}, 1 \mathrm{H}) ;{ }^{13} \mathrm{C}$ NMR $\left(125 \mathrm{MHz}, \mathrm{DMSO}-d_{6}\right): \delta 188.0$, 161.6, 148.8, 145.7, 136.3, 136.2, 135.4, 128.1, 128.0, 127.9, 126.5, 125.8, 123.7, 122.2, 120.6, 115.5, 113.7; LC-MS (m/z): $290(\mathrm{M}+\mathrm{H})^{+}$, positive mode; Anal. 
calcd. for $\mathrm{C}_{17} \mathrm{H}_{11} \mathrm{~N}_{3} \mathrm{O}_{2}: \mathrm{C}, 70.58 ; \mathrm{H}, 3.83 ; \mathrm{N}, 14.53 \%$, found: C, $70.45 ; \mathrm{H}, 3.78 ; \mathrm{N}, 14.43 \%$.

2.1e 2-(4-(Dimethylamino)phenyl)quinazolin-4(3H)one (5): White solid; yield: $92 \%, \mathrm{Mp}: 222^{\circ} \mathrm{C}$, IR (KBr) $v_{\max }: 3188,3015,1670,1588,1528,1363,1287$, 1204, 936, 821, 766, $459 \mathrm{~cm}^{-1} ;{ }^{1} \mathrm{H}$ NMR $(400 \mathrm{MHz}$, $\left.\mathrm{CDCl}_{3}\right): \delta 11.03(\mathrm{~s}, 1 \mathrm{H}), 8.30(\mathrm{~d}, 1 \mathrm{H}, J=7.8 \mathrm{~Hz})$, $8.11(\mathrm{~d}, 2 \mathrm{H}, J=8.8 \mathrm{~Hz}), 7.76-7.74(\mathrm{~m}, 2 \mathrm{H}), 7.43-$ $7.39(\mathrm{~m}, 1 \mathrm{H}), 6.79$ (d, 2H, $J=8.8 \mathrm{~Hz}), 3.07(\mathrm{~s}, 6 \mathrm{H})$; ${ }^{13} \mathrm{C}$ NMR $\left(100 \mathrm{MHz}, \mathrm{CDCl}_{3}\right): \delta 163.7,152.5,151.8$, 150.1, 134.6, 128.8, 128.5, 127.4, 126.3, 125.6, 120.3, 119.2, 112.0, 111.6, 40.1; LC-MS (m/z): $266(\mathrm{M}+\mathrm{H})^{+}$ positive mode; Anal Calcd for $\mathrm{C}_{16} \mathrm{H}_{15} \mathrm{~N}_{3} \mathrm{O}$ : C,72.43; $\mathrm{H}, 5.70 ; \mathrm{N}, 15.84 \%$; found $\mathrm{C}, 72.54 ; \mathrm{H}, 5.62 ; \mathrm{N}$, $15.76 \%$.

2.1f 2-(1H-Pyrrol-2-yl)quinazolin-4(3H)-one (6): White solid; yield: $94 \%$, Mp: $240^{\circ} \mathrm{C}$, IR (neat) $v_{\max }$ : 3430, 2252, 2126, 1665, 1539, 1501, 1468, 1052, 1024, 986, $827 \mathrm{~cm}^{-1} ;{ }^{1} \mathrm{H}$ NMR $\left(400 \mathrm{MHz}, \mathrm{CDCl}_{3} / \mathrm{DMSO}-\right.$ $\left.d_{6}\right): \delta 12.01(\mathrm{~s}, 1 \mathrm{H}), 11.17(\mathrm{~s}, 1 \mathrm{H}), 8.08(\mathrm{~d}, 1 \mathrm{H}$, $J=7.8 \mathrm{~Hz}), 7.62-7.58(\mathrm{~m}, 1 \mathrm{H}), 7.54-7.52(\mathrm{~m}, 1 \mathrm{H})$, 7.28-7.24 (m, 2H), $6.92(\mathrm{~s}, 1 \mathrm{H}), 6.15(\mathrm{~s}, 1 \mathrm{H}) ;{ }^{13} \mathrm{C} \mathrm{NMR}$ $\left(100 \mathrm{MHz}, \mathrm{CDCl}_{3} / \mathrm{DMSO}-d_{6}\right): \delta 161.5,148.4,145.1$, 133.0, 125.3, 124.8, 123.8, 123.4, 122.1, 119.4, 111.3, 108.8; LC-MS (m/z): $212(\mathrm{M}+\mathrm{H})^{+}$positive mode, Anal Calcd for $\mathrm{C}_{12} \mathrm{H}_{9} \mathrm{~N}_{3} \mathrm{O}$ : C, 68.24; H, 4.29; N, $19.89 \%$; found $\mathrm{C}, 68.36 ; \mathrm{H}, 4.35 ; \mathrm{N}, 19.76 \%$.

2.1g 2-(Pyridin-2-yl)quinazolin-4(3H)-one (7): White solid, yield: $92 \%, \mathrm{Mp}: 138^{\circ} \mathrm{C}$, IR (KBr) $v_{\max }$ : 3265, 1670, 1593, 1467, 1319, 1139, 991, 799, $739,684,601 \mathrm{~cm}^{-1} ;{ }^{1} \mathrm{H}$ NMR $\left(400 \mathrm{MHz}, \mathrm{CDCl}_{3}\right): \delta$ $10.94(\mathrm{~s}, 1 \mathrm{H}), 8.63(\mathrm{~d}, 1 \mathrm{H}, J=4.6 \mathrm{~Hz}), 8.54(\mathrm{~d}, 1 \mathrm{H}$, $J=8.0 \mathrm{~Hz}), 8.32(\mathrm{~d}, 1 \mathrm{H}, J=8.0 \mathrm{~Hz}), 7.90-7.86(\mathrm{~m}$, 1H), 7.80-7.74 (m, 2H), 7.51-7.43 (m, 2H); ${ }^{13} \mathrm{C}$ NMR $\left(100 \mathrm{MHz}, \mathrm{CDCl}_{3}\right): \delta$ 161.0, 149.1, 148.8, 148.7, $148.3,137.5,134.5,128.0,127.2,126.7,126.2,122.4$, 121.9; LC-MS (m/z): $224(\mathrm{M}+\mathrm{H})^{+}$positive mode; Anal Calcd for $\mathrm{C}_{13} \mathrm{H}_{9} \mathrm{~N}_{3} \mathrm{O}: \mathrm{C}, 69.95 ; \mathrm{H}, 4.06 ; \mathrm{N}, 18.82 \%$; found: $\mathrm{C}, 69.85 ; \mathrm{H}, 4.12 ; \mathrm{N}, 18.75 \%$.

2.1h 2-(Quinolin-2-yl)quinazolin-4(3H)-one (8): White solid; yield: $95 \%$, Mp: $188^{\circ} \mathrm{C}$, IR $(\mathrm{KBr}) v_{\max }$ : 3320, 1687, 1599, 1555, 1407, 1325, 1237, 1122, 925, $837,739,623 \mathrm{~cm}^{-1} ;{ }^{1} \mathrm{H}$ NMR (400 $\left.\mathrm{MHz}, \mathrm{CDCl}_{3}\right)$ : $\delta 11.16(\mathrm{~s}, 1 \mathrm{H}), 8.56(\mathrm{~d}, 1 \mathrm{H}, J=8.4 \mathrm{~Hz}), 8.33(\mathrm{~d}, 1 \mathrm{H}$, $J=7.8 \mathrm{~Hz}), 8.28(\mathrm{~d}, 1 \mathrm{H}, J=8.4 \mathrm{~Hz}), 8.08(\mathrm{~d}, 1 \mathrm{H}$, $J=8.4 \mathrm{~Hz}), 7.83-7.81(\mathrm{~m}, 2 \mathrm{H}), 7.78-7.72(\mathrm{~m}, 2 \mathrm{H})$, $7.58(\mathrm{t}, 1 \mathrm{H}, J=7.4 \mathrm{~Hz}), 7.49(\mathrm{t}, 1 \mathrm{H}, J=7.4 \mathrm{~Hz})$;
${ }^{13} \mathrm{C}$ NMR (100 MHz, $\left.\mathrm{CDCl}_{3}\right): \delta 161.4,149.0,148.8$, 147.9, 146.6, 137.5, 134.5, 130.4, 129.6, 129.2, 128.2, 127.7, 127.5, 126.7, 122.5, 118.3; LC-MS (m/z): 274 $(\mathrm{M}+\mathrm{H})^{+}$positive mode; Anal Calcd for $\mathrm{C}_{17} \mathrm{H}_{11} \mathrm{~N}_{3} \mathrm{O}: \mathrm{C}$, 74.71; H, 4.06; N, $15.38 \%$; found: C 74.62; H, 4.14; N $15.42 \%$.

2.1i 2-(9-Ethyl-9H-carbazol-3-yl)quinazolin-4(3H)one (9): White solid; yield: $91 \%, \mathrm{Mp}: 232^{\circ} \mathrm{C}$, IR $(\mathrm{KBr}) v_{\max }$ : 3051, 2853, 2328, 1682, 1589, 1556, 1506, 1468, 1287, $772 \mathrm{~cm}^{-1}$; ${ }^{1} \mathrm{H}$ NMR (400 MHz, $\left.\mathrm{CDCl}_{3} / \mathrm{DMSO}-d_{6}\right): \delta 12.15(\mathrm{~s}, 1 \mathrm{H}), 9.05(\mathrm{~s}, 1 \mathrm{H}), 8.38$ $(\mathrm{d}, 1 \mathrm{H}, J=7.6 \mathrm{~Hz}), 8.29(\mathrm{~d}, 1 \mathrm{H}, J=7.8 \mathrm{~Hz}), 8.21$ (d, $1 \mathrm{H}, J=7.6 \mathrm{~Hz}), 7.81-7.45(\mathrm{~m}, 2 \mathrm{H}), 7.52-7.49(\mathrm{~m}$, 2H), 7.47-7.41 (m, 2H), $7.29(\mathrm{t}, 1 \mathrm{H}, J=7.3 \mathrm{~Hz}), 4.40$ $(\mathrm{q}, 2 \mathrm{H}, J=7.2 \mathrm{~Hz}), 1.45(\mathrm{t}, 3 \mathrm{H}, J=7.2 \mathrm{~Hz}) ;{ }^{13} \mathrm{C} \mathrm{NMR}$ $\left(100 \mathrm{MHz}, \mathrm{CDCl}_{3} / \mathrm{DMSO}_{6}\right): \delta 163.1,152.5,149.2$, $141.1,139.9,133.8,126.9,125.7,125.6,125.2,124.9$, $122.8,122.4,120.27,120.20,119.9,119.0,108.4$, 108.1, 37.1, 13.3; LC-MS (m/z): $340(\mathrm{M}+\mathrm{H})^{+}$positive mode; Anal Calcd for $\mathrm{C}_{22} \mathrm{H}_{17} \mathrm{~N}_{3} \mathrm{O}$ : C, 77.86; $\mathrm{H}, 5.05$; $\mathrm{N}, 12.38 \%$; found $\mathrm{C}, 77.69 ; \mathrm{H}, 5.14, \mathrm{~N}, 12.45 \%$.

\section{Results and discussion}

We first examined a synthetic route starting from a reaction of indole-2-aldehyde (1) with anthranilamide (2), chosen as the model substrates to optimize the reaction conditions. In the presence of $\mathrm{CuBr}$ and 2.0 equivalent of $\mathrm{K}_{2} \mathrm{CO}_{3}$ (relative to the amount of indole-2-aldehyde 1) at $120^{\circ} \mathrm{C}$, this coupling reaction proceeded smoothly, to give a indolylquinazolinone 3 in $74 \%$ yield.

The influence of the catalyst, ligand, base, solvent and temperature were examined as shown in table 1 . In the initial screenings, different bases like $\mathrm{Cs}_{2} \mathrm{CO}_{3}$, $\mathrm{Na}_{2} \mathrm{CO}_{3}$, KOAc, and $\mathrm{K}_{2} \mathrm{CO}_{3}$ were tested in the reaction. Also, the effect of solvents were investigated and it was found that DMF afforded good yield compared to the various solvents which were investigated in this reaction. We found that $\mathrm{Cs}_{2} \mathrm{CO}_{3}$ proved to be the most effective base in DMF. It may be due to maximum solubility as well as basicity of $\mathrm{Cs}_{2} \mathrm{CO}_{3}$ particularly in DMF than that of other bases used in the optimization of the reaction. ${ }^{10}$

When $\mathrm{CuI}$ was used as the catalyst in place of $\mathrm{CuBr}$, it showed weaker activity than $\mathrm{CuBr}$ (table 1 , entry 3). Other copper catalysts were also evaluated but proved less effective than $\mathrm{CuBr}$. The condensation of $\mathbf{1}$ and $\mathbf{2}$ proceed neither at room temperature nor below $70^{\circ} \mathrm{C}$. No product formation was observed in the absence of catalyst (table 1, entry 12). The optimal reaction temperature was also examined, and the yield 
Table 1. Optimization condition for the copper catalyzed synthesis of indolylquinazolinone. ${ }^{\text {a }}$

\begin{tabular}{|c|c|c|c|c|c|}
\hline S. No & Catalyst & Base & Solvent & Time(H) & Yield $^{\mathrm{d}}(\%)$ \\
\hline 1 & $\mathrm{CuBr}$ & $\mathrm{K}_{2} \mathrm{CO}_{3}$ & DMF & 2 & 74 \\
\hline 2 & $\mathrm{CuBr}$ & KOAc & DMF & 6 & 48 \\
\hline 3 & $\mathrm{CuI}$ & $\mathrm{Cs}_{2} \mathrm{CO}_{3}$ & DMF & 4 & 85 \\
\hline 4 & $\mathrm{CuBr}$ & $\mathrm{Cs}_{2} \mathrm{CO}_{3}$ & NMP & 8 & 10 \\
\hline 5 & $\mathrm{Cu}(\mathrm{OAc})_{2}$ & $\mathrm{Cs}_{2} \mathrm{CO}_{3}$ & DMF & 6 & 84 \\
\hline $6^{\mathrm{b}}$ & $\mathrm{CuBr}$ & $\mathrm{Cs}_{2} \mathrm{CO}_{3}$ & DMF & 2 & 94 \\
\hline 7 & $\mathrm{CuI}$ & $\mathrm{Cs}_{2} \mathrm{CO}_{3}$ & DMSO & 8 & 20 \\
\hline 8 & $\mathrm{CuBr}$ & $\mathrm{Na}_{2} \mathrm{CO}_{3}$ & DMF & 12 & 72 \\
\hline 9 & $\mathrm{CuCl}$ & $\mathrm{Cs}_{2} \mathrm{CO}_{3}$ & DMSO & 12 & 35 \\
\hline 10 & $\mathrm{CuBr}$ & $\mathrm{Cs}_{2} \mathrm{CO}_{3}$ & Toluene & 12 & 22 \\
\hline 11 & $\mathrm{CuI}$ & $\mathrm{K}_{2} \mathrm{CO}_{3}$ & DMF & 4 & 72 \\
\hline 12 & - & $\mathrm{Cs}_{2} \mathrm{CO}_{3}$ & DMF & 12 & - \\
\hline $13^{\mathrm{c}}$ & $\mathrm{CuBr}$ & $\mathrm{Cs}_{2} \mathrm{CO}_{3}$ & DMF & 5 & 68 \\
\hline
\end{tabular}

${ }^{a}$ Unless otherwise mentioned, all the reactions were conducted in a RB using indole-2-aldehyde $\mathbf{1}$ (1.0 equiv.), anthranilamide 2 (1.0 equiv.) catalyst (10 mol \%), base (2.0 equiv.) $3 \mathrm{~mL}$ solvent stirred at $120{ }^{\circ} \mathrm{C}$ in open air. ${ }^{\mathrm{b}} 3$ equiv. of base used. ${ }^{\mathrm{c}} 5 \mathrm{~mol} \%$ catalyst used. $\mathrm{d}^{\mathrm{i}}$ isolated yields

of the target product reached a maximum at $120^{\circ} \mathrm{C}$ under open air condition. Without ligand and additive the reaction proceeded well within $2 \mathrm{~h}$. By decreasing the $\mathrm{CuBr}$ loading from $10 \mathrm{~mol} \%$ to $5 \mathrm{~mol} \%$, the reaction took longer reaction time for the completion (table 1. entry 13).

Based on above findings, we concluded that the optimal condition for this reaction involves 1.0 equiv. of $\mathbf{1}$, 1.0 equiv. of 2 and 3.0 equiv. of $\mathrm{Cs}_{2} \mathrm{CO}_{3}$ in DMF with $10 \mathrm{~mol} \%$ of $\mathrm{CuBr}$ at $120^{\circ} \mathrm{C}$ in open air. By using the above optimized condition the product $\mathbf{3}$ was obtained in excellent yield (94\%) within $2 \mathrm{~h}$. To achieve the synthesis of bouchardatine alkaloid $\mathbf{4}$ we conducted the formylation reaction of $\mathbf{3}$, following the reported procedure[6a] using $\mathrm{DMF} / \mathrm{POCl}_{3}$ at $0^{\circ} \mathrm{C}$ for $24 \mathrm{~h}$ which yielded the $\mathbf{4}$ in $91 \%$ yield (scheme 2).
With the optimized reaction conditions in hand, we next moved to synthesis of different quinazolinone derivatives (5-9) by varying different (hetero)aryl aldehydes with anthranilamide $\mathbf{2}$ and the reactions proceeded well to give quinazolinone derivatives in excellent yields (table 2). The proposed mechanism is shown in scheme 3.

We proposed a plausible pathway in scheme 3 , where the first step is the reaction between aldehyde $\mathbf{1}$ and the amine $\mathbf{2}$, which led to the formation of corresponding imine (A). Next, the imine nitrogen is activated by the $\mathrm{CuBr}$, which increases the elctrophilicity of the imine that undergoes a ready attack by the amide nitrogen to form the cyclized quinazolinone ring $(\mathbf{C})$ and regenerate the $\mathrm{CuBr}$. Then the cyclized ring is aromatized by aerobic oxidation to form $\mathbf{3}$.

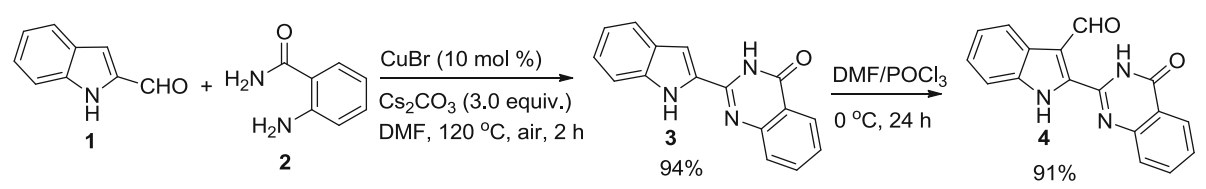

Scheme 2. Synthesis of bouchardatine alkaloid (4). 
Table 2. Synthesis of (hetero)aryl substituted quinazolinone. ${ }^{\text {a }}$<smiles>CN(C)c1ccc(-c2nc3ccccc3c(=O)[nH]2)cc1</smiles><smiles>CC(C)[R6](=O)(O)OC(=O)c1cc(=O)[nH]c(-c2ccc3ccccc3n2)n1</smiles><smiles>O=c1[nH]c(-c2ccc[nH]2)nc2ccccc12</smiles>

$6,94 \%, 1 \mathrm{~h}$<smiles>O=c1[nH]c(-c2ccccn2)nc2ccccc12</smiles>

7, $92 \%, 30 \mathrm{~min}$<smiles>CCn1c2ccccc2c2cc(-c3nc4ccccc4c(=O)[nH]3)ccc21</smiles>

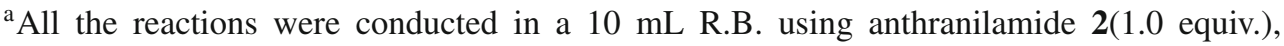
(hetero)arylaldehyde (1.0 equiv.), $\mathrm{Cs}_{2} \mathrm{CO}_{3}$ (3.0 equiv.), $\mathrm{CuBr}(10 \mathrm{~mol} \%), \mathrm{DMF}(3 \mathrm{~mL})$, $120^{\circ} \mathrm{C}$, open air.

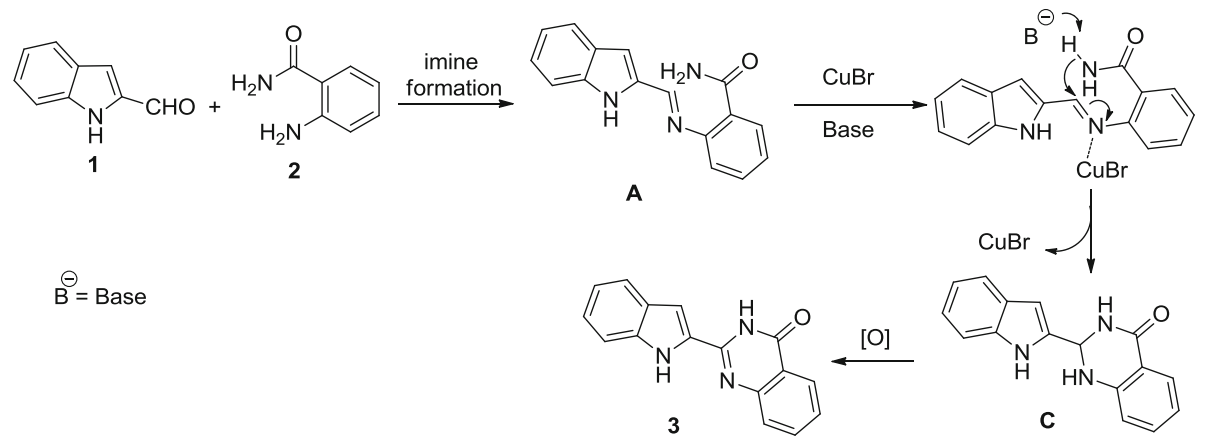

Scheme 3. Proposed mechanism for the formation of $\mathbf{3}$.

\section{Conclusion}

In summary, we have developed an efficient coppercatalyzed synthesis of indolylquinazolinone derivative in good yield. This reaction proceeds well under relatively moderate conditions with shorter reaction times. By formylation of the above product, bouchardatine was prepared in good yield. We synthesized various (hetero)aryl substituted quinazolinone derivatives in good yields using the above optimized oxidation reaction condition.

\section{Supplementary Information}

The electronic supporting information can be seen at www.ias.ac.in/chemsci.

\section{Acknowledgements}

We thank the Department of Science and Technology (DST) (Project number: SR/S1/OC-70/2008) for financial support. M V thanks the Council of Scientific and Industrial Research (CSIR) for a Senior Research Fellowship.

\section{References}

1. (a) Mhaske S B and Argade N P 2006 Tetrahedron 62 9787; (b) Grundon M F 1984 Nat. Prod. Rep. 1 195; (c) Michael J P 2000 Nat. Prod. Rep. 17603

2. (a) Witt A and Bergman J 2003 Curr. Org. Chem. 7 659; (b) Johne S Rodd's 1995 Chemistry of Carbon Compounds (supplements to the 2nd Ed.) (ed) Ansell M F (Amsterdam: Elsevier) Vol. IV I/J, pp 223; (c) Brown D J 1996, Quinazolines. In The Chemistry of Heterocyclic Compounds, Volume 55, Quinazolines: Supplement 1 (New York: Wiley); (d) Connolly D J, Cusack D, O'Sullivan T P and Guiry P J 2005 Tetrahedron 61 10153; (e) Liang J L, Cha H C and Jahng Y 2011 Molecules 16 4861; (f) Nacro K, Zha C, Guzzo P R, Herr R J, Peace D and Friedrich T D 2007 Bioorg. Med. Chem. 154237

3. Wattanapiromsakul C, Forster P I and Waterman P G 2003 Phytochemistry 64609 
4. Richards PG 1991 Bouchardatia Vol. 2 Harden G, (Ed.), (Sydney: New South Wales University Press)

5. Forster P I 2002 Rutaceae R J F Henderson (Ed.), (Brisbane: Queensland Government, Environmental Protection Agency)

6. (a) Bubenyák M, Palfi M, Takacs M, Beni S, Eva S, Noszal B and Kokosi J 2008 Tetrahedron Lett. 49 4937; (b) Naik N H, Urmode T D, Sikder A K and Kusurkar R S 2013 Aust. J. Chem. 661112

7. (a) Jana R, Pathak T P and Sigman M S 2011 Chem. Rev. 111 1417; (b) Engle K M, Mei T S, Wang X and Yu J Q 2011 Angew. Chem., Int. Ed. 50 1478; (c) Bras J L and Muzart J 2011 Chem. Rev. 111 1170; (d) Chen $\mathrm{X}$, Wang H, Jin X, Feng J, Wang Y and Lu P 2011 Chem. Commun. 47 2628; (e) Luo Y, Pan X and Wu J 2011 Org. Lett. 13 1150; (f) Armstrong A and Collins J C 2010 Angew. Chem., Int. Ed. 49 2282; (g) Zhao D B, You J S and $\mathrm{Hu}$ C W 2011 Chem.- Eur. J. 175466

8. For general reviews on palladium-catalyzed transformations and synthesis of heterocycles, see: (a) Magano J and Dunetz J R 2011 Chem. Rev. 111 2177; (b) Majumdar K C, Chattopadhyay B K, Maji P K, Chattopadhyay S and Samanta S 2010 Heterocycles 81 795; (c) Song G, Wang F and Li X 2012 Chem. Soc.
Rev. 41 3651; (d) Neufeldt S R and Sanford M S 2012 Acc. Chem. Res. 45 936; (e) Kuhl N, Hopkinson M N, Wencel D J and Glorius F 2012 Angew. Chem., Int. Ed 51 10236; (f) Mousseau J J and Charette A B 2013 Acc. Chem. Res. 46412

9. For reviews and papers on copper-catalyzed coupling reactions, see: (a) Lanting $X$, Yinsheng P, Qiangbiao P, Yongwen J and Dawei M 2013 J. Org. Chem. 78 3400; (b) Allen S E, Walvoord R R, Salinas R P and Kozlowski M 2013 Chem. Rev. 113 6234; (c) Xiaolin P, Yong L and Jie W 2013 J. Org. Chem. 78 5756; (d) Chen D S, Dou G L, Li Y L, Liu Y and Wang X S 2013 J. Org. Chem. 78 5700; (e) Biswas S and Batra S 2013 Eur. J. Org. Chem. 4895; (f) Jhan Y H, Kang T W and Hsieh J C 2013 Tetrahedron Lett. 54 1155; (g) Chen D, Chen Q, Liu M, Dai S, Huang L, Yang J and Bao W 2013 Tetrahedron 69 6461; (h) Ngi S I, Guilloteau V, Abarbri M and Thibonnet J J 2011 Org. Chem. 76 8347; (i) Xu W, Jin Y, Liu H, Jiang Y and Fu H 2011 Org. Lett. 13 1274; (j) Sreenivas D K, Ramkumar N and Nagarajan R 2012 Org. Biomol. Chem. 103417

10. (a) Salvatore R N, Nagle A S and Jung K W 2002 J. Org. Chem. 67 674; (b) Wolfe J P and Buchwald S L 2000 J. Org. Chem. 651144 